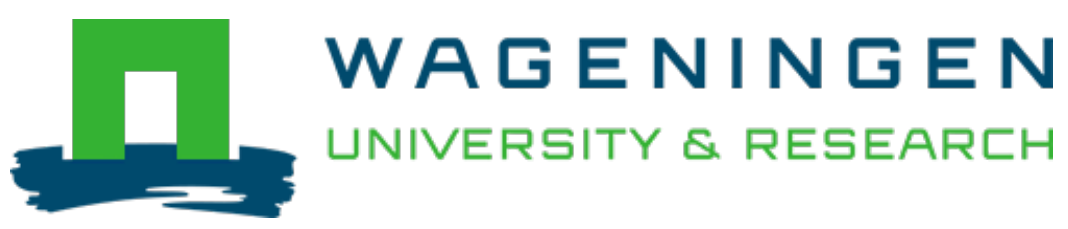

\title{
Development of microsatellite markers in Gonystylus bancanus (Ramin) useful for tracing and tracking of wood of this protected species
}

\author{
Molecular Ecology Resources \\ Smulders, M.J.M.; Westende, W.P.C.; Diway, B.; Esselink, G.D.; Meer, P.J. et al \\ https://doi.org/10.1111/j.1471-8286.2007.01914.x
}

This article is made publicly available in the institutional repository of Wageningen University and Research, under the terms of article $25 \mathrm{fa}$ of the Dutch Copyright Act, also known as the Amendment Taverne. This has been done with explicit consent by the author.

Article 25 fa states that the author of a short scientific work funded either wholly or partially by Dutch public funds is entitled to make that work publicly available for no consideration following a reasonable period of time after the work was first published, provided that clear reference is made to the source of the first publication of the work.

This publication is distributed under The Association of Universities in the Netherlands (VSNU) 'Article $25 \mathrm{fa}$ implementation' project. In this project research outputs of researchers employed by Dutch Universities that comply with the legal requirements of Article $25 \mathrm{fa}$ of the Dutch Copyright Act are distributed online and free of cost or other barriers in institutional repositories. Research outputs are distributed six months after their first online publication in the original published version and with proper attribution to the source of the original publication.

You are permitted to download and use the publication for personal purposes. All rights remain with the author(s) and / or copyright owner(s) of this work. Any use of the publication or parts of it other than authorised under article $25 \mathrm{fa}$ of the Dutch Copyright act is prohibited. Wageningen University \& Research and the author(s) of this publication shall not be held responsible or liable for any damages resulting from your (re)use of this publication.

For questions regarding the public availability of this article please contact openscience.library@,wur.nl 
PRIMER NOTE

\title{
Development of microsatellite markers in Gonystylus bancanus (Ramin) useful for tracing and tracking of wood of this protected species
}

\author{
M. J. M. SMULDERS, ${ }^{*}$ W. P. C. VAN 'T WESTENDE, ${ }^{*}$ B. DIWAY,+G. D. ESSELINK, \\ P. J. VAN DER MEER and W. J. M. KOOPMAN* \\ *Plant Research International, Wageningen UR, 6700 AA Wageningen, The Netherlands, †Forest Research Centre, Kuching, 93250 \\ Sarawak, Malaysia, $\ddagger$ Alterra Green World Research, Wageningen UR, 6700 AA Wageningen, The Netherlands
}

\begin{abstract}
Ten polymorphic microsatellite markers have been developed for Gonystylus bancanus (Ramin), a protected tree species of peat swamp forests in Malaysia and Indonesia. Eight markers were also shown to be polymorphic in other Gonystylus species. The markers will enable assessing the amount of genetic variation within and among populations and the degree of population differentiation, such that donor populations can be selected for reforestation projects. They may be used for tracing and tracking of wood in the production chain, so that legal trade in this Convention on International Trade in Endangered Species of Wild Fauna and Flora-protected timber species, derived from specifically described origins, can be distinguished from illegally logged timber.
\end{abstract}

Keywords: CITES, logging, peat swamp, Sarawak

Received 17 May 2007; revision accepted 19 June 2007

Peat swamp forests are threatened tropical ecosystems because of extensive forest conversion into agricultural land and other uses. As a typical peat swamp tree, Gonystylus bancanus (Ramin) still has a wide distribution in Malaysia and Indonesia, but the number of adult individuals within populations is rapidly decreasing, even though the species is protected (IUCN 2006). For the Sarawak government's effort to restore them, ecological and population-genetic aspects of this species should be considered. This includes the amount of genetic variation present and the degree of population differentiation, which is important information for selection of the most suitable donor populations for reforestation. To be able to study the population genetics, we have developed microsatellite markers.

Genomic DNA of Gonystylus bancanus was isolated from leaf samples of 20 trees from two populations in Sarawak (Malaysia) with the QIAamp DNA Stool Mini Kit (QIAGEN). In addition, DNA was extracted from 47

Correspondence: M.J.M. Smulders, Fax: +31 317 418094; E-mail: rene.smulders@wur.nl samples of seven other Gonystylus species, also collected in Sarawak (Table 2). Di- and trinucleotide repeat microsatellite loci were isolated from a genomic DNA library using an enrichment procedure after Karagyozov et al. (1993) as modified by and described in detail by van de Wiel et al. 1999) and Esselink et al. (2003). In short, 500 ng genomic DNA was restricted-ligated with AluI, RsaI or HaeIII, pooled and amplified. Microsatellite-containing fragments were selected by hybridization to Hybond $\mathrm{N}+$ membranes with separately spotted synthetic oligonucleotides: $(\mathrm{GT})_{12}$ $(\mathrm{GA})_{12}(\mathrm{TCT})_{10}(\mathrm{TGT})_{10}(\mathrm{TGA})_{9}(\mathrm{AGT})_{9}(\mathrm{CGT})_{8}(\mathrm{GCT})_{8}$ $(\mathrm{GCC})_{7}$. The fragments were eluted from the membranes with increasing stringencies, up to $0.1 \%$ sodium dodecyl sulphate for $10 \mathrm{~min}$ at $100{ }^{\circ} \mathrm{C}$. Eluted fragments were precipitated, re-amplified and cloned. The clones were screened for the presence of repeat sequences by spotting and hybridization with 33P-labelled oligonucleotides. We obtained 2446 colonies of which 193 (7.9\%) were positive: 134 from the (GT) enrichment, 19 from the (GA) enrichment, and only 40 from all trinucleotide motifs together. Twenty-seven unique repeats were identified with sufficient flanking sequences to enable primer design using PRIMERSELECT (DNAStar). Reverse primers were 
Table 1 Characteristics of the microsatellite markers developed

\begin{tabular}{|c|c|c|c|c|c|c|c|c|c|c|c|}
\hline Locus* & $\begin{array}{l}\text { EMBL } \\
\text { Accession no. }\end{array}$ & $\begin{array}{l}\text { Repeat } \\
\text { motift }\end{array}$ & Primer sequences $\left(5^{\prime}-3^{\prime}\right)$ & Dye§ & Calculated $T_{\mathrm{m}}$ & $\begin{array}{l}\text { Size of cloned } \\
\text { fragment (bp) }\end{array}$ & QualityII & $\begin{array}{l}\text { Number } \\
\text { of alleles** }\end{array}$ & $\begin{array}{l}\text { Effective } \\
\text { number of allelest+ }\end{array}$ & $H_{\mathrm{O}}$ & $H_{\mathrm{E}}$ \\
\hline WGb06 & AM423091 & $(\mathrm{CGG})_{11-4}$ & $\begin{array}{l}\text { F: CTTGGCCAGATCGACCCTCGACTT } \\
\text { R: GTTTGTTCCCCCGTCGGTGATGATTTTC }\end{array}$ & NED & 62 & 207 & 1 & 5 & 1.7 & 0.3 & 0.425 \\
\hline WGb17 & AM423093 & $(\mathrm{TCT})_{7-1}$ & $\begin{array}{l}\text { F: GTAGTCATTAACGGTGGGAAGGTT } \\
\text { R: GTTTGTTATCAATGCACTACAAAGACC }\end{array}$ & NED & 50 & 315 & 1 & 12 & 7.3 & 0.85 & 0.886 \\
\hline WGb22 & AM423096 & $(\mathrm{GT})_{18}$ & $\begin{array}{l}\text { F: GCACGCAAGGCCTATCTGAGTGTA } \\
\text { R: GTTTGAGGGATGTGGTAGAGGGAAACT }\end{array}$ & NED & 57 & 290 & 2 & 9 & 4.4 & 0.65 & 0.79 \\
\hline WGb23 & AM423097 & $(\mathrm{GT})_{21}$ & $\begin{array}{l}\text { F: TTGAGAGGGCGACACATTGAGAGT } \\
\text { R: GTTTGCATATGTGTATGGCATGTGATGTA }\end{array}$ & 6-FAM & 58 & $>311$ & 2 & 7 & 4 & 0.6 & 0.769 \\
\hline WGb24 & AM423098 & $(\mathrm{GT})_{18}$ & $\begin{array}{l}\text { F: AGGGCACAACTTCATGGGCATCA } \\
\text { R: GTTTGAACCCGAACTTATAGGTGACAGC }\end{array}$ & HEX & 53 & 341 & 2 & 9 & 5.2 & 0.75 & 0.827 \\
\hline WGb29 & AM423099 & $(\mathrm{GT})_{23-2}$ & $\begin{array}{l}\text { F: ATGATAGTCACGCAAATGATGGTG } \\
\text { R: GTTTCCGCCCTAAAGTTGCAATAAAGT }\end{array}$ & NED & 53 & 129 & 2 & 11 & 6.5 & 0.65 & 0.867 \\
\hline WGb32 & AM423101 & $(\mathrm{GA})_{23}$ & $\begin{array}{l}\text { F: CTCAAAACACAATCAACAGAAAAT } \\
\text { R: GTTTCTTTGATGAAGACGAAGAAATGT }\end{array}$ & 6-FAM & 51 & 312 & 2 & 16 & 10.3 & 0.8 & 0.926 \\
\hline WGb37 & AM423104 & $(\mathrm{GT})_{9}$ & $\begin{array}{l}\text { F: ACGCGTGCAGTGGGCAGGTG } \\
\text { R: GTTTCCAAAACCAGAAGGCTCAAAACAA }\end{array}$ & HEX & 55 & 170 & 1 & 7 & 4.1 & 0.7 & 0.777 \\
\hline WGb38 & AM423105 & $(\mathrm{GT})_{11}$ & $\begin{array}{l}\text { F: TTTTCTTTGCCAAGGATTTATCTT } \\
\text { R: GTTTAATTATTGGAGCAGCACACTACAA }\end{array}$ & HEX & 52 & 280 & 1 & 6 & 3.4 & 0.65 & 0.723 \\
\hline WGb39 & AM423106 & $(\mathrm{GT})_{11}$ & $\begin{array}{l}\text { F: CATGGCTTGCCAAATATACATAGG } \\
\text { R: GTTTAAGGCAAGGCTTCATCAAATCTTC }\end{array}$ & 6-FAM & 53 & 156 & 2 & 5 & 2.6 & 0.6 & 0.633 \\
\hline
\end{tabular}

*In addition, nine other polymorphic microsatellite markers of poorer quality [rated according to Smulders $e t$ al. (1997) as quality 3 (many stutter bands that hamper accurate genotyping) and quality 4 (additional products amplified)] were submitted to the EMBL database as well: AM423089, AM423090, AM423092, AM423094, AM423095, AM423100, AM423102, AM423103 and AM423107; tminus sign denotes mismatch; fincluding pigtail (GTTT; Brownstein et al. 1996); §the forward primers were dye-labelled; FAM- and HEX-labelled primers as well as unlabelled primers were from Biolegio (Nijmegen, The Netherlands). NED-labelled primers were from Applied Biosystems; Iqquality rating according to Smulders et al. (1997); quality 1: clear products, easily scorable; quality 2: few stutter bands but well scorable; **in 20 plants from two populations on Sarawak; $++N e, H_{\mathrm{O}}$ and $H_{\mathrm{E}}$ calculated with POPGENE 1.32 (Yeh et al.; http://www.ualberta.ca/ fyeh/info.htm); Hardy-Weinberg and linkage disequilibrium among loci was calculated with FSTAT 2.9.3 (Goudet, J. 2001. FSTAT, a program to estimate and test gene diversities and fixation indices (version 2.9.3). Available from http://www2.unil.ch/popgen/softwares/fstat.htm). 
Table 2 Result of the cross-species amplification of the 10 microsatellite markers on samples from seven other Gonystylus species

\begin{tabular}{|c|c|c|c|c|c|c|c|}
\hline \multirow[b]{2}{*}{$\begin{array}{l}\text { Microsatellite } \\
\text { marker }\end{array}$} & \multicolumn{7}{|c|}{$\begin{array}{l}\text { Species } \\
\text { (number of plants tested) }\end{array}$} \\
\hline & $\begin{array}{l}\text { G.affinis } \\
\text { (6) }\end{array}$ & $\begin{array}{l}\text { G.borneensis } \\
\text { (4) }\end{array}$ & $\begin{array}{l}\text { G.micranthus } \\
\text { (9) }\end{array}$ & $\begin{array}{l}\text { G.lucidulus } \\
\text { (9) }\end{array}$ & $\begin{array}{l}\text { G.forbesii } \\
\text { (2) }\end{array}$ & $\begin{array}{l}\text { G.nobilis } \\
\text { (8) }\end{array}$ & $\begin{array}{l}\text { G.stenosepalus } \\
\text { (9) }\end{array}$ \\
\hline WGb06 & $\mathrm{P}^{*}$ & Pn & $\mathrm{P}$ & $\mathrm{P}$ & $\mathrm{P}$ & $\mathrm{P}$ & $\mathrm{Pu}$ \\
\hline WGb17 & $\mathrm{Pu}$ & $\mathrm{Pu}$ & $\mathrm{P}$ & $\mathrm{Pu}$ & $\mathrm{P}$ & Pnu & Pn \\
\hline WGb22 & - & - & - & $-t$ & - & $-t$ & $-t$ \\
\hline WGb23 & - & - & - & - & - & - & - \\
\hline WGb24 & Pn & Pn & Pn & $\mathrm{P}$ & $\mathrm{P}$ & $\mathrm{P}$ & $\mathrm{P}$ \\
\hline WGb29 & $\mathrm{P}$ & $\mathrm{P}$ & $\mathrm{P}$ & $\mathrm{P}$ & $\mathrm{P}$ & $\mathrm{P}$ & $\mathrm{P}$ \\
\hline WGb32 & Pn & Pn & $\mathrm{P}$ & Pn & $\mathrm{P}$ & Pn & $\mathrm{P}$ \\
\hline WGb37 & $\mathrm{P}$ & $\mathrm{P}$ & $\mathrm{P}$ & $\mathrm{P}$ & $\mathrm{P}$ & $\mathrm{P}$ & $\mathrm{P}$ \\
\hline WGb38 & $\mathrm{P}$ & $\mathrm{Pu}$ & $\mathrm{P}$ & $\mathrm{P}$ & $\mathrm{P}$ & Pn & $\mathrm{P}$ \\
\hline WGb39 & $\mathrm{P}$ & $\mathrm{P}$ & $\mathrm{Pu}$ & $\mathrm{Pu}$ & $\mathrm{P}$ & $\mathrm{Pu}$ & $\mathrm{P}$ \\
\hline
\end{tabular}

${ }^{*} \mathrm{P}$, amplification of polymorphic bands; $n$, no amplification in two or more samples; $\mathrm{u}$, probably null alleles (inferred from an excess of homozygotes); -, no amplification; tamplification observed in one plant, which was heterozygous.

pigtailed by adding a GTTT sequence at the $5^{\prime}$-end. This was carried out as Taq DNA polymerases may add a nontemplate adenosine to the $3^{\prime}$-end of some products during the polymerase chain reaction (PCR). Pigtailing leads to nearly $100 \%$ adenylation of the $3{ }^{\prime}$-end of the forward strand (Brownstein et al. 1996), which facilitates the interpretation of the peaks and therefore contributes to accurate genotyping (Bredemeijer et al. 1998). Amplification was performed in $20-\mu l$ reaction volume containing $10 \mathrm{ng}$ of genomic DNA, 4 pmol of each primer, $100 \mu \mathrm{M}$ of each dNTP, $10 \mathrm{~mm}$ Tris-HCL pH 9.0, $20 \mathrm{~mm}\left(\mathrm{NH}_{4}\right)_{2} \mathrm{SO}_{4^{\prime}}$ $0.01 \%$ Tween 20, 2-2.5 $\mathrm{mm} \mathrm{MgCl}_{2}$ and $0.2 \mathrm{U}$ GoldstarTaq DNA polymerase (Eurogentec). PCR conditions were $94{ }^{\circ} \mathrm{C}$ for 3 min followed by 30 cycles of $94^{\circ} \mathrm{C}$ for $30 \mathrm{~s}, 50^{\circ} \mathrm{C}$ for $30 \mathrm{~s}, 72{ }^{\circ} \mathrm{C}$ for $45 \mathrm{~s}$ and a final extension at $72{ }^{\circ} \mathrm{C}$ for $10 \mathrm{~min}$, using a slope of $1^{\circ} \mathrm{C} / \mathrm{s}$, on an MJ PTC200. Amplification products were separated on a $6 \%$ denaturated polyacrylamide gel and visualized by silver staining (Promega Silver Sequence DNA Sequencing System). Of the 27 loci, 19 were polymorphic. In line with the relative frequency of repeats in the positive clones, most of these were (GT) repeats, and only two (WBg05 of poor quality and WBg06 of good quality) were trinucleotide repeats.

We selected the most easily scorable markers (see Table 1). For these 10 markers, we amplified samples from 20 plants with fluorescently labelled primers, separated them on an ABI PRISM 3700, and analysed the results using GENOTYPER 3.1 (Applied Biosystems). The markers amplified 5-16 different alleles. The effective number of alleles ranged from 1.7 (for WBg06, the only trinucleotide repeat marker) to 10.3 . Consistent with the outbreeding behaviour of the tree species, most sampled trees were heterozygous at these polymorphic loci. Observed heterozygosity was between 0.6 and 0.85 for all markers except WBg06, for which it was only 0.3. No deviation from Hardy-Weinberg was detectable, and the loci were not in linkage disequilibrium with each other. The percentage positive clones $(7.9 \%)$ and the fraction of polymorphic markers from these clones $(9.8 \%$ ) are in the range of about $10 \%$ efficiency for each of the steps, as we have often found in microsatellite enrichments in other species, including tree species (van de Wiel et al. 1999; Van der Schoot et al. 2000; Pastorelli et al. 2003).

We also tested the 10 markers on samples from seven other Gonystylus species on an ABI PRISM 3700 (Table 2). WBg23 did not amplify in any species, and WBg22 only rarely, but the eight other markers consistently amplified polymorphic bands in the other species, although with some drop-out of samples (depending both on marker and species). Null alleles were very likely present in some species for markers WBg17 and WBg39.

The microsatellite markers developed here will enable studying genetic diversity and population differentiation of Ramin populations in Malaysia and Indonesia, such that donor populations can be selected for reforestation projects. In addition, they may be useful for tracing and tracking of wood in the production chain (Koopman \& Diemont 2004), so that legally logged wood (from specific sites or plantations) can be distinguished from illegally logged wood.

\section{Acknowledgements}

This work was funded by the Netherlands' Ministry of Agriculture, Nature and Food Safety, North-South program. 


\section{References}

Bredemeijer GMM, Arens P, Wouters D, Visser D, Vosman B (1998) The use of semi-automated fluorescent microsatellite analysis for tomato cultivar identification. Theoretical and Applied Genetics, 97, 584-590.

Brownstein ML, Carpten JD, Smith JR (1996) Modulation of non-templated nucleotide addition by Taq DNA polymerase: primer modifications that facilitate genotyping. BioTechniques, 20, 1004-1010.

Esselink GD, Smulders MJM, Vosman B (2003) Identification of cut rose (Rosa hybrida) and rootstock varieties using robust sequence tagged microsatellite markers. Theoretical and Applied Genetics, 106, 277-286.

IUCN (2006) Red List of Endangered Species. International Union for the Conservation of Nature and Natural Resources, Gland, Switzerland. Available from URL: http://www.iucnredlist.org/.

Karagyozov L, Kalcheva ID, Chapman M (1993) Construction of random small-insert genomic libraries highly enriched for simple sequence repeats. Nucleic Acid Research, 21, 3911-3912.
Koopman WJM, Diemont H (2004) Prospects for the molecular identification of CITES-protected timber species and origins. North-South Policy Brief 2004-3. http://www.pri.wur.nl/NR/ rdonlyres/F0A577A6-A96E-4D07-8F0B-3E93BBF7240D/8814/ Policy20045.pdf.

Pastorelli R, Smulders MJM, Van 'T Westende WPC et al. (2003) Characterisation of microsatellite markers in Fagus sylvatica L. \& Fagus orientalis Lipsky. Molecular Ecology Notes, 3, 76-78.

Smulders MJM, Bredemeijer G, Rus-Kortekaas W, Arens P, Vosman B (1997) Use of short microsatellites from database sequences to generate polymorphisms among Lycopersicon esculentum cultivars and accessions of other Lycopersicon species. Theoretical and Applied Genetics, 94, 264-272.

Van der Schoot J, Pospíšková M, Vosman B, Smulders MJM (2000) Development and characterization of microsatellite markers in Black Poplar (Populus nigra L.). Theoretical and Applied Genetics, 101, 317-322.

van de Wiel C, Arens P, Vosman B (1999) Microsatellite retrieval in lettuce (Lactuca sativa L.). Genome, 42, 139-149. 